\title{
Şiirde Düşünmek: Melih Cevdet Anday ve Özdemir Asaf'in Şiirleri Üzerine Gözlemler
}

\section{Thinking in Poetry: Observations on the Poems of Melih Cevdet Anday And Özdemir Asaf}

\author{
Alphan Akgül ${ }^{1}$
}

${ }^{1}$ Dr. Öğretim Üyesi, İstanbul 29 Mayıs Üniversitesi, Türk Dili ve Edebiyatı Bölümü, İstanbul, Türkiye

ORCID: A.A. 0000-0002-2381-0247

Sorumlu yazar/Corresponding author: Alphan Akgül,

İstanbul 29 Mayıs Üniversitesi, Türk Dili ve Edebiyatı Bölümü, İstanbul, Türkiye

E-mail: alphanakgul@gmail.com

Başvuru/Submitted: 24.12 .2020

Revizyon Talebi/Revision Requested: 15.01.202 Son Revizyon/Last Revision Received: 12.02 .2021 Kabul/Accepted: 26.02.2021

\section{Atıf/Citation:}

Akgul, A. (2021). Siirde Düșünmek: Melih

Cevdet Anday ve Özdemir Asaf'in şiirleri üzerine gözlemler. TUDED, 61(1), 21-44. https://oi.org/10.26650/TUDED2020-846431

\section{ÖZET}

Şiir sanatı üzerine yapılan çalışmalarda ses ve imge baskın bir rol oynar. Düzyazı ile şiir dili arasında yapılan ayrımların doğal bir sonucu olarak, şiir sanatının söylevden ayrı, ses ve imge gibi dış dünyanın somut verilerine dayanan bir sanat olduğu görüşü hâkimdir. Buna karşın, şiirde düşünce, kimi zaman didaktik kimi zaman da şiirsel bir derin düşünme șeklinde, ses ve imgeden bağımsız olarak ortaya çıkmaktadır. Özellikle, duyguların denetimsiz bir şekilde dışa vurulduğu romantik şiire karşı çıkan modernist şairlerin akla yaptıkları vurgu, bu makalenin ağırlık noktasını oluşturur. Modernist şairler kalbin çığlığı yerine zihnin çığlı̆̆ını tercih etmişler; modern yaşamın buhranını düşünsel yönü ağır basan şiirlerle dile getirmişlerdir. Modern Türk şiirinde de bu yönde eser veren şairlere rastlanır. Bu makalede, ilkin, Türk edebiyatında fikir şiirleri hakkında genel bir bilgi verilecek, ardından Eliot ve Pound'un görüşleri özetlenecek, sonra da Melih Cevdet Anday ve Özdemir Asaf'ın ses ve imgeden çok düşünceyi öne çıkardıkları şiirleri tartışılacaktır.

Anahtar Kelimeler: Şiirde düşünce, metafizik şiir, akıl ürünü, Melih Cevdet Anday, Özdemir Asaf

\section{ABSTRACT}

In studies on the art of poetry, sound and image play a dominant role. As a natural consequence of the differences between prose and poetic language, the prevailing view is that poetry is an art separate from discourse based on sound, image, and concrete data from the outside world. In poetry, thoughts occasionally occur in didactic form and deep thinking, independent of sound and image. Modernist poets emphasized reason and opposed romantic poetry, where emotions find free expression. They preferred the cry of the mind to the cry of the heart. They expressed the depression of modern life in poems that outweighed the intellectual aspect. In modern Turkish poetry, some poets give works in this direction. This article begins with general information on the poems and ideas in Turkish literature. Next, Eliot and Pound's views will be summarized, followed by Melih Cevdet Anday and Özdemir Asaf's work, where thoughts are highlighted rather than sound and image.

Keywords: Thought in poetry, metaphysical poetry, logopoeia, Melih Cevdet Anday, Özdemir Asaf 


\section{EXTENDED ABSTRACT}

Poetry is literary art in which sound and visual images feature extensively. Therefore, the text analysis on poetry focuses on auditory and visual images. In Ottoman lyric poetry, music and visual images are more important than intellectual content. Modern Turkish poetry is the same. The French symbolists, who influenced Turkish poetry for a long time, tried to bring poetry to non-verbal music as much as possible by seeing thought as an element that sullied its purity. Yahya Kemal Beyatlı and Ahmet Haşim, referring to the symbolists, emphasized form and musical features of the language, more than meaning or idea, as essential in poetry. Therefore, the idea that poetry should be lyrical and musical became dominant in modern Turkish poetry. The transformation started in the 1950s and ended the dominance of sound patterns in poetry. By this time, visual images became dominant in poetry. The focus of poetic became the images that appeared in journals and books of that period. As verbal expression intensified in poetry, voice patterns or imaginary associations rather than ideas and meanings gained prominence. For the reader, poetry expresses a multidimensional visual world. There is no specific subject covered in these poems. Instead, there are image patterns and word associations that readers or critics must carefully decipher.

The prominence of sound and image in Turkish poetry studies neglected logical expressions. However, poetic expressions with logical propositions, such as humor, irony, and satire, have always been important in traditional and modern poetry. The philosophical style in Divan poetry (hikemî tarz), mystical teachings in Sufi poetry, in which conceptual issues such as freedom and equality after Tanzimat, show that poetry has an intellectual aspect. Even Tevfik Fikret, devoted to the aesthetics of poetry, especially its sound features, engaged in political discussions and put forth idealism in the most striking poems of his poetry career. In the poems of Yahya Kemal and Ahmet Haşim, followers of pure poetry, we come across lines that read like a philosophical proposition. There is always an intellectual aspect in the works of poets such as Nazım Hikmet, Necip Fazıl, Fazıl Hüsnü Dağlarca, and Orhan Veli Kanık although they have different styles and content. Although the poems of the "Second New" poets that emerged in the 1950s were interpreted as meaningless and abstract by the critics of the period, thought played an important role in the poems of these poets. These examples make it necessary to discuss the subject of thought in modern poetry, especially in modern Western poetry, where it is never excluded. How?

Modern Western poetry is not a follower of pure poetry, whose supporters claim that "all arts aspire the condition of music." On the contrary, the prominent modernist poets of the twentieth century react to the chaotic era in which they live and therefore oppose both the sentimental poetry of the romantics and the melodic poetry in which the symbolists destroy the meaning and seek only an ambiguous purity. It does not mean that there is no emotion or musicality in their poetry; these poets transcend traditional poetic styles by equipping emotion with critical mind and musicality with intense intellectual content. Modernist poets bring intellectualism to poetry. They refer to mythology and anthropology and deal with the tension 
between tradition and modernism. In doing so, they always add a philosophical dimension to their poems. Thus, T. S. Eliot glorifies poets such as John Donne and Andrew Marvell, who were known as metaphysical poets and were active in the seventeenth century, because they could melt reason and emotion in a single pot. Ezra Pound, on the other hand, adds logical poetry (logopoeia) to his poetics, as well as sound and image. In modern Turkish poetry, some poets put the emotional side to the background and emphasize the mind, intelligence, and wit. In the poems of Melih Cevdet Anday and Özdemir Asaf, the lyrical expressions representing the "heart-cry" are replaced by the "mind cry," and the visual imagery is supplanted by the "logical eye" that examines everything with a critical perspective. 


\section{GİRIŞ}

Şiirin somut ve duyumsanabilir ögeleri ses ve imgedir ama dilin işlevleri arasında soyut düşünceyi iletmek de vardır. Genellikle şiir, dilin soyut ve kavramsal özelliklerini geri plana iten bir sanat türü olarak görülür. Bu nedenle şiirin ses ve imge ögelerinin öne çıktığ1, düşünce boyutunun arka plana atıldığ 1 öne sürülebilir. Şiir, dilin dokusunu yoğunlaştırma, onu görünür kılma çabası olarak da tanımlanır. Böylelikle şiirin somut yönü, dilin dokusunun da bu sanata dâhil edilmesiyle pekiştirilir. Öyle ki şiir fikrî içeriğinden çok müzik ve resimle karşılaştırılır; şiirin içindeki müzikten, görsel özelliklerden söz edilir. Ayrıca şiirde kullanılan ses örgülerinin veya bazı seslerin grafik (tipografik) özelliklerinin anlatılan konuyla olan ilişkisi araştırılabilir. Oysa bütün bunların yanı sıra şiirde bazen açıkça bazen de örtük bir şekilde ileri sürülen fikirler de vardır. Şiir bir söylev sanatı değildir ama retorik sanatı şiirin bir parçasıdır ve kimi şairler, şiirlerinden belli bir fikrin anlaşılmasını veya sezilmesini isterler. Kimi şairler ise şiiri saf bir müzik sanatı olarak gördüğünden her türlü düşünce ögesinin bu saflığı bozduğunu ileri sürmektedir. Bu ikisi arasında bir denge kurmaya çalışan, düşünce şiiri içinde melodiyi, lirik şiir içinde düşünceyi korumaya çalışan şairler de vardır. Zaten şiirin ağırlık noktasının ses ve imge olduğu da tartışmalıdır. Terry Eagleton örneğin, şiirde dilin maddi ögelerinin öne çıktığı düşüncesinin yaygın olmasına karşın, bunun kuramsal bir yaklaşım olduğunu söyler ve bu kurama uygun şiir bulmanın zor olduğunu belirtir: " $\mathrm{Bu}$ teorinin sorunu, bizim şiir olarak adlandırdığımız metinlerin çoğunun böyle bir görünüm sunmuyor olmasıdır" (Eagleton, 2011, s. 67). Gerçekten de, şiir antolojilerini karıştırdığımızda, anlamı unutturacak ölçüde melodik bir yapının veya imgelerin öne çıktığı şiirlerin sanıldığı kadar çok sayıda olmadığı görülebilir. Ses ve imge kadar, içinde belli bir fikir barındıran şiirlerin sayısı da az değildir.

Şiir sadece beş duyudan alınan izlenimlerin sanatsal bir dönüşüme uğratılarak dışa vurulması değildir. Aynı zamanda şiir, bir düşünme eylemini gerekli kılar. Hem şiirin oluşumunda hem de iletiminde bir fikrî arka plan olabilir. Kimi şairler işitsel ve görsel imgelere ağırlık verirken kimi şairler de şiirin düşünce boyutuyla ilgilidirler. Garip önsözünde, şiirde tedahüle, yani sanatların bir arada kullanılmasına bu yüzden karşı çıkılır. Şiir, musikiye benzetildiğinde, seslerin melodik organizasyonu, musikiye göre çok zayıf kalır veya şiir resme benzetildiğinde harflerin birer görsel imge gibi kullanılması yine onu resme göre zayıf bir sanat hâline getirir. Oysa şiir kendine has bir sanattır ve dilin ana işlevi, belli bir anlamı iletmektir (Orhan Veli, 2013, s. 25). Kurucularından biri olduğu "Garip" akımının bu fikirlerini ileri bir boyuta taşıyarak düşünce şiirine yönelen Melih Cevdet Anday, bu görüşü bir şiirle de ifade eder. Anday, Charles Baudelaire'in "Eşduyumlar" başlıklı şiirinde geçen "sembol ormanları" ifadesini eleştirir: "Sembol ormanları demişti Baudelaire, / İmgesiz düşünemez miyiz" (Anday, 1997, s. 306). Bu soru şiirde soyut düşünce açısından hayati bir öneme sahiptir. Çünkü şiirin hep somut imgelerle işlediği görüşüne aykırı bir tavır almanın yanı sıra, modern şiirin kurucularından Baudelaire'in simgeci şiirine de bir başkaldırı içerir. Anday, somut imgeci tutumun dışında, bir düşünce şiiri de olabileceğini öne sürmüş olur bu dizeleriyle. Şiirde bir yazım yöntemi olarak düşünceye ağırlık vereceğini açıkça dile getiren bir başka 
şair ise Özdemir Asaf’tır (2011). Şair, "Poetika" şiirinde şöyle söyler: "Bana düşünmek vardı, payıma onu aldım / İşledim de işledim bir hüner-işi gibi” (s. 228). Bilindiği üzere poetika, bir şairin yöntemini belirtir ki Özdemir Asaf da bu şiirle, kendi mizacına uygun düşen şiirin düşünce şiiri olduğunu ifade eder. Asaf'ın şiirleri tarandığında, pek çok şiirine "düşünce” ve "anlam”la ilgili başlıklar verdiği kolaylıkla görülebilir. Görüldüğü üzere modern Türk şiirinde, ses ve imgeci şiirin dışında, bir şiir yazım yöntemi olarak soyut düşünmeyi tercih eden şairler vardır. Bu makalede, düşünce şiiri, hem Türk şiir geleneğinden hem de Batı şiirinden örneklerle irdelenecek, ardından Melih Cevdet Anday ve Özdemir Asaf'ın niçin düşünce şairi olarak görüldükleri tartışılacaktır.

\section{Makalenin Kuramsal Çerçevesi}

$\mathrm{Bu}$ çalışma belli bir kuramın uygulaması, örneğin varoluşçuluk vb. bir felsefi yaklaşımın Türk şiirine uyarlanması değildir. Daha çok şiirde düşünmenin bir yöntem olarak kullanıldığı şiirler ele alınıp irdelenecektir. T. S. Eliot, "Metafizik Şairler " başlıklı makalesinde akıl ve duygu arasında bağ kuran, duygusal konuların zekâ ile ele alınıp işlendiği şiirlerden söz etmiştir. Bu kavrama Murat Belge (2018), Şairaneden Şiirsele adlı kitabında, Özdemir Asaf'ın şiirini tartışırken atıf yapar (s. 368). Bu çarpıcı atıf, Mehmet Kaplan'ın Özdemir Asaf'ın şiirlerine getirdiği yorumlarla bir arada değerlendirilecektir. Bunun yanı sıra, makalenin çerçevesi, Ezra Pound'un modern şiirde bir eğilim olarak gördüğü akıl, nükte ve zekâ oyunlarına dayanan bir şiir üslubuyla doğrudan ilgilidir. Bilindiği üzere Pound, şiiri “ezgi ürünü” (melopoeia), “imge ürünü” (phanopoeia) ve “akıl ürünü” (logopoeia) olarak üç başlık altında irdelemeyi önerir. Onun bu görüşleri makalenin şiirde düşünce olarak belirlenen ana çerçevesine uygun düşer. Gelgegelim, Pound'un logopoeia kavramı, logos'un aklın yanı sıra "kelam” anlamını da vermesi nedeniyle "söz ürünü” olarak da tanımlanabilir. Nitekim Pound, bu tür şiiri, "zihnin sözcükler ve fikirler arasında dansı" (a dance of the intelligence among words and ideas) olarak tanımlar (Pound, 1973, s. 424). Her ne kadar Pound'un bu kavramı, "sözcük oyunu" veya “metafor”la ilişkilendirilmiş olsa da (Schiralli, 1981, ss. 26-27) kavramın ana çerçevesi, şiirin zihinsel bir yönü olduğu vurgusu üzerindedir. Bu nedenle, Pound'un görüşleri, şiirin akılla ilişkisi açısından tartışmaya dâhil edilecektir. Zaten eleştirmen Orhan Koçak da (2012), bir yazısında, bu kavramı tam da bu makalenin iddiasına uygun bir şekilde, "mantık şiiri” olarak tanımlamıştır (s. 274). Bunların yanı sıra, Mahmut Temizyürek (2021) Behçet Necatigil'in "hikmet burcu" ifadesinden yola çıkarak, şiir ile düşünce arasındaki gerilimi tarihsel bir bakış açısıyla ele alarak "mitos" ile "logos" arasındaki ayırımla irdeleyen bir deneme yazmış ve Anday’ın şiirlerinde akılcı düşünceyle mitik düşüncenin nasıl iç içe kurgulandığını öne sürmüştür. Onun bu görüşlerinin bir benzerine, Mehmet Kaplan'ın Anday üstüne yazdığı bir yazıda -farklı bir ifade tonuyla da olsa- rastlanır. Kısaca makale, T. S. Eliot ve Ezra Pound'un çizdiği kuramsal çerçeveyle birlikte, Kaplan, Belge, ve Koçak’ın yorumlarından yola çıkarak modern Türk şiirinde akla, mantığa ve zekâ oyunlarına dayanan şiirin önemini ve anlamını belirleme amacını gütmektedir. 


\section{Türk Şiirinde Düşünce Üzerine Genel Bir Bakış}

Türk şiirinde düşünce gibi genel bir kavramın izini sürmek kolay değildir, zaten bu makalenin amacı da bu değildir. Bu makalede modern Türk şiirinin iki şairinin şiirlerindeki soyut / kavramsal eğilimler tartışılacaktır ama bu tartışmaya bir zemin olması açısından, Türk şiiri tarihinden düşünce şiiriyle ilgili bazı gözlemler aktarılabilir. Düşünce dendiğinde akla ilk gelen şiir tarzlarından biri tasavvuf öğretisiyle ilgili eserlerdir. Bu eserlerde lirik bir coşkunluk, vecd hâli olduğu kadar, tasavvufi öğretinin esasları da yer alır. Fuad Köprülü örneğin, Türk Edebiyatında İlk Mutasavvıflar başlıklı eserinde, Yunus Emre'nin bu iki yönünü de vurgular ama onun şiirinde ana eğilimin "mutasavvıfane hikmet" olduğu tespitini de yapar. Köprülü şöyle söyler:

Mutasavvıfane bir vecd ve huşu“ içinde bâzan aşkın ulvî ve esrar dolu mâhiyetinden, bâzan Kiyâmet gününün korkulu velvelesinden, bâzan da Cennet'in sütlü 1rmaklarından ve ilahî bülbüllerin Vahdâniyyet nağmelerinden bahseden Âşık Yûnus, bütün Türk mutasavvıfları gibi, tabi’ata karşı tamâmen kayıdsız kalamaz. Dîvân-ı Lügāt'it-Türk' deki eski Türk şiirlerinde ve Kutadgu Bilig'de tabi'ata karş1 nasıl bir heyecan, bir incizab varsa, Sakarya ormanlarında meczûbâne dolaşan Yûnus'un eserlerinde de az-çok bir tabi' at zevkı mevcuddur; lakin gözleri iç âlemin derinliklerinden kurtulamadığı için, Dîvân'ındaki pek az tabi'at levhalarında bile yine vicdânî renkler, safhalar göze çarpıyor ve netice mutlaka hiç beklenmeyen bir tarzda, yâni ya bir ahlâkî öğüt, ya bir mutasavvıfâne hikmet şeklinde zuhûr ediyor. (Köprülü, 1976, s. 296)

Köprülü'nün bu yorumu, şiirin ses ve imge yoğunluğunun ötesinde, ahlaki bir öğüt şeklini de alabileceğini gösterir. Her ne kadar Köprülü buna eleştirel bir tavır geliştirse de, tasavvufi şiirlerde coşkun ruh hâllerinin lirik bir yansıması olan şiirlerin dışında, didaktik bir yön de bulunduğunu anlarız. Bunun bir benzerini divan şiirinde de görmek mümkündür. Divan şiirinde "hayal" olarak tarif edilen görsel imgeler yaygındır, ayrıca ses örgüleri, ritmik tekrarlar da bu şiirin lirik yönünü destekler. Ancak, divan şiirinde de, hikemî bir üslubun varlığı bilinir. Nâbi örneğin, divan şiirinde hikemî üslubun temsilcisi olarak görülür: Çünkü Nâbi, "Şiirlerinde okuyucusuna sürekli öğüt verip yol gösteren bir tavır takınmıştır” (Şentürk, 2006, s. 520).

Şiirde fikrî arka planın divan şiirinden yenileşme devrine doğru bir süreklilik arz ettiğini gösteren çarpıcı bir örnek, Sabri F. Ülgener'in, Bağdatlı Rûhi ve Ziya Paşa'nın terkîb-i bentleri üstüne yaptığı bir karşılaştırmadır. Bu yazısında Ülgener, devirlerinden şikâyet eden iki şairin farklı tutumlarına dikkat çeker. Rûhi, mütevekkil ve içe dönük bir şekilde sızlanırken, Ziya Paşa hırslı ve öfkeli bir bürokrat kimliğiyle çağını eleştirir. Her ne kadar üslupları farklı olsa da iki şair için de şiir salt estetik bir amaca hizmet etmez; onlar için şiir bir düşünce aracıdır. Rûhi, "Ne câh'a rağbetimiz var ne çarh'a minnetimiz" veya "âlemi bir huzura sattık biz" derken (alıntılayan Ülgener, 2006, s. 38), ses ve imge aracılığıyla bir şiirsel etki peşinde değildi. Bu dizeleriyle Rûhi, şeyh ve eşraf takımının egemen olduğu feodal düzenin çarpık 
maddi hırslarından uzakta, ruhsal açıdan dingin bir yaşama arzusunu anlatmakta, manevi dünyanın huzuruyla yetindiğini dile getirmektedir. Ziya Paşa ise yüksek perdeden konuşur; tepkilerini öfkeli bir dille yansıtmaktan çekinmez: "Milyonla çalan mesned-i izzette [s]er-efrâz" (alıntılayan Ülgener, 2006, s. 41) diyerek çağının tersine dönmüş değer sistemini sorgular.

On dokuzuncu yüzyıl felsefi sorunların işlenmesi için de uygun bir tarihsel zemindir. Âkif Paşa örneğin, “Adem Kasidesi”nde, klasik şiirin ana motiflerinden ayrılıp bir varlık sorununu işler. Ahmet Hamdi Tanpınar, Âkif Paşa'nın felsefi anlamda klasik kültürle köprüleri attığını şu sözlerle dile getirir:

Şair kendisine kadar, edebiyatımızda ancak vahdet-i vücud sistemlerinin bir diyalektik unsuru olarak kullanılmış olan bir mefhumu birdenbire varlığın karşısına dikmek, onun üzerine yüklenmekle, farkında olmadan bütün bir sistemin dışına çıkar. Fakat [P]aşa, acaba yaptığının hakikaten farkında değil miydi? Çünkü eski cemiyette tabii olan sığınmalara (Allah, peygamber, veliler, cemiyet planında hükümdar, devlet adamları, vesaire...) karşı yokluk fikrine böyle sı̆̆ınmanın, onu övmenin bizzat kendisi, velev tek bir eserde olsun — ki Âkif Paşa'da böyledir - tahminimizden çok büyük köprüleri atmaktadır. Daha manzumeye başlarken:

Can verir âdeme endîşe-i sahbâ-yı adem

Cevher-i can mı aceb cevher-i mînâ-yı adem

beytinin ilk mısraında ölüm düşüncesiyle kurtuluş fikrini birleştirirken, ikinci mısrada yokluk birdenbire hayatın özü (essence) oluverir. (Tanpınar, 2013, s. 106)

Ayrıca Âkif Paşa, "İki kâğıttan ibaret nüsâh-1 kevn ü mekân / Biri ibka-yı vücud u biri ifnâ-yı adem" beyitinde, evrenin birbiriyle çatışan iki güç üstüne kurulu olduğunu bir varlık felsefecisi tavrıyla ifade etmektedir. Ona göre kâinat, iki kâğıttan ibaret bir kitaptır; bunlardan biri yaşamı var etmeye, diğeriyse yok etmeye uğraşır (Kaplan, 2005, s. 26).

Görüldüğü üzere bu tip şiirlerde dil bir önerme aracıdır; bir fikri dile getirme aracıdır şiir o yüzden. Tanzimat döneminde bir kamuoyu yaratma amacı güderek gazeteciliğin yerleşmesinde büyük rol oynayan Şinasi'nin şiirlerinde, aklın egemenliği fikrinin şiirlere yansıması bilinçli bir propaganda faaliyeti ürünüdür. Kendisine aydınlanmacı bir görev biçen Şinasi için dil estetik bir sanattan çok bir kitle iletişim aracıdır. "Dilin iradesini başta akleder tedbir / Ki tercüman-i lisandır anı eden takrir” dizelerinde şair, aklın önceliğini vurgular ve lisanın aklın tercümanı olduğunu söyler (Şinasi, 1945, s. 12). Ayrıca Şinasi, "Vahdet-i zâtına aklımca şahadet lâzım / Can ü gönlümle münacat ü ibadet lâzım” diyerek şiiri bir felsefi / dinî tartışma alanı olarak gördüğünü açıkça ifade etmiş olur (Şinasi, 1945, s. 6). Nâmık Kemal ise, Leskofçalı Galib’in "Olup mecrûh-i peykân-1 havâdis tâir-i devlet / Demâdem hûn akar çeşmim gibi enzâr-1 milletten" beyitini okuyunca, şiirde sosyal temaların nasıl işleneceğini görür ve "Hürriyet Kasidesi”nin ilk kıvılcımını bu beyitten alır (Kaplan, 2005, s. 42). 
Ses ögesini şiirin ayrılmaz bir parçası hâline getiren şairlerde de düşünce boyutu baskın bir unsur olarak ortaya çıkabilir. Tevfik Fikret' in şiirlerinde ses ahengini ne derece etkili kullandığı, Mehmet Kaplan'ın şair üzerine yaptığı çalışmanın “Üslup” bölümünden rahatlıkla anlaşılır. Oysa bütün bu ses organizasyonu, Fikret' in şiirlerinde öne sürdüğü görüşleri pekiştirme amac1 da taşır. Başka bir ifadeyle Fikret, ses örgülerine büyük önem verdiği hâlde, şiirleriyle düşünce üreten bir sanatçıdır. Bu yüzden Fuad Köprülü, Halûk'un Defteri üzerine kaleme aldığı yazılarda, Fikret' in bu kitabıyla birlikte estetik gayeden uzaklaşıp söylev şiirine geçtiğini belirtmiş ve bu yeni yönelimi eleştirmiştir. Köprülü’nün eleştirisi, Fikret'in bir ruhsal dönüşüm geçirerek bir fikir şairi olmakta karar kılmasına yöneliktir. Hatta Köprülü, Fikret'in Suly Prudhomme gibi bir fikir şairi olduğunu iddia ederek onu savunanları da eleştirir çünkü şiiri bir fikir sanatı olarak görmenin çıkışsız bir yol olduğunu düşünmektedir; öyle ki Köprülü, Prudhomme’un bile bu konuda başarısızlığa uğradığını belirtir (Köprülü, 2011, s. 392). Fikret bu kitabıyla sanatı, sanat için yapmaktan vazgeçip onu bir fikrin iletimi için gerekli bir araç olarak görmeye başlamıştır:

[E]ski devrin son senelerine doğru duçar olduğu istihalât neticesinde, sanatı bir gayeden daha ziyade bir vasıta gibi kullanmağa başlayan Tevfik Fikret Bey, nihayet öyle bir noktaya vâsıl oldu ki, artık o zaman düşünen ve ağlayan bir ruhun elemlerini terennüm etmek, inleyen bir kalbe hitap eylemek imkânsızdır; o zaman muhayyile ve hassasiyet denilen menâbi-i sanat kurur; ve seviye-i zevkiyesi avamınkinden az yüksek bir dereceye düşen sanatkâr, ihtilâl cemaatlerini tehyic ve sevk eden rehberler gibi, ateşîn ve cazip hutbelerle bütün bir kitleye hitap eder. (Köprülü, 2011, ss. 393-94)

Burada muhayyile ile hutbe arasındaki fark, esasında lirik şiir ile fikir şiiri arasındaki farka karşılık gelmektedir. Şiirin hayal gücüne dayalı, somut izlenimlerin mecazlara dökülmesi olarak değil de, kavramsal ve düşünce odaklı bir şekilde yazılmasına itiraz etmektedir Köprülü. Fikret, bu şiirlerinde gençliğe yol gösterme çabasındadır. Oğlu Haluk'u ülkede inkılap yapacak gençliğin simgesi olarak görür Fikret: "Şair oğlunu memleketi kurtaracak bir kahraman olarak görüyor. Halûk, Avrupa'ya gidecek, orada 'pür-tehâlük, hayat ve kuvvetten ne bulursa, sanat, fen, itimat, itina, cesaret, ümit' hepsini yüklenerek yurda getirecek” (Kaplan, 1995, s. 167). Benzer şekilde, Mehmet Âkif Ersoy’un şiirinde de fikir ön plandadır: Şiir tarzını tanıtmak için yazdığı şiirinde "Ne tasannu bilirim, çünkü ne san'atkârım” diyen şair (Mehmet Âkif, 1966, s. 3), şiirsel bakışını sosyal ve siyasal eleştiri üzerinde yoğunlaştırmıştır: "Bir sahne demek âleme pek doğrudur elbet / Ancak; görülen vak'aların hepsi hakikat" dizelerinde (s. 19) Âkif, Shakespeare'in (2018) bir oyununda geçen "Bütün dünya bir sahnedir / Kadın, erkek bütün insanlar da oyuncular” (s. 46) sözünü hatırlatır ama oynanan bütün oyunların gerçekliğine vurgu yapar ki bu da bir sosyal mesaj olarak yorumlanabilir.

Fikir ileri sürmek, her şairin eserleri arasında görülebilir; o şairin üslubundaki baskın nokta lirik veya saf şiir olsa bile. Yahya Kemal (1969) örneğin, Türk şiirinde ses ögesinin simge isimlerinden biridir. Saf şiire olan eğilimi nedeniyle didaktik şiirlerden uzak olması gerektiği de varsayılabilir. Genel hatlarıyla öyledir de ama onun şiirlerinde de fikrî önerme 
denebilecek dizelere rastlanır: "Çok insan anlıyamaz eski mûsikîmizden / Ve ondan anlamıyan bir şey anlamaz bizden” (s. 34) dizelerinde şair, kendi şiiri ile klasik Türk musikisi arasındaki bağlantının şiirlerini anlamada kilit bir rol oynadığını ileri sürmektedir. Bu dizeler lirik olmaktan çok bir önerme havası taşır. Ahmet Haşim'in (2013) "Melâli anlamayan nesle âşinâ değiliz" (s. 149) dizesinde de benzer bir şikâyet dile getirilir. Şair, kadın ve erkeği maddi bir bakışla gören zihniyetin melâl duygusunu anlayamayacağını, bu duyguyu hissetmeyenlerin de şiirlerini kavrayamayacağını iddia etmektedir. Necip Fazıl'ın (1997), “Mezar, mezar, zıtların kenetlendiği nokta; / Mezar, mezar, varlığa yol veren geçit, yokta... / Onda sırların sırrı: Bulmak için kaybetmek" (s. 171) dizeleri ise şiirin ses ve imge yönünden çok düşünsel ve metafizik boyutunu ilgilendirir. Fazıl Hüsnü Dağlarca (2014) daha ilk kitabında şöyle der örneğin: "Düşünüyorum tabiattan büyük varlığımı uzun uzun" (s. 83). Ahmet Hamdi Tanpınar da (2011) saf ve lirik şiiri savunur ama onun "Ne içindeyim zamanın, / Ne de büsbütün dışında; / Yekpâre, geniş bir ânın / Parçalanmaz akışında” dizeleri (s. 19), düşünür Henri Bergson’un zaman anlayışının bir özeti gibidir.

Nâzım Hikmet'in şiirlerinde ise materyalist felsefenin savunusu ve bununla at başı giden fikrî söz dalaşı havasına sık rastlanır. Materyalist felsefeyi savunduğu için idealist felsefeci Berkeley'i eleştiren Nâzım Hikmet'in (2010) şu dizeleri bu görüşe bir örnektir: "Felsefenden tüten günlük kokusu / başımızı döndürmek içindir / Hayat kavgasında bizi / dizüstü süründürmek içindir" (s. 65) dizeleri bir söz dalaşı tarzında yazılmıştır. "Yok üstünde tabiatın / tabiattan gayri kuvvet" ise bir felsefi önermedir (s. 72). Nâzım, rubaileri, tam da bu türün doğasına uygun bir şekilde, fikrî şiir yazmak için kullanır: "Bir gerçek âlemdi gördüğün ey Celâleddin, heyhûla filân değil / uçsuz bucaksız ve yaratılmadı, ressamı illetîûlâ filân değil” (s. 731). Ercüment Behzat Lav'ın "İmperatorluklar madik atarlar birbirlerine / Alır İngiliz altını kıt'anın güdümünü üzerine / Diriltemez Hasta Adam'1 Nizâm-1 cedîd ve Tanzîmat-1 Hayriyye" (alıntılayan Kahyaoğlu, 2015, s. 185) dizelerinde ise bir tarihsel eleştiri üslubu vardır. Nâzım'ın açtığı yoldan ilerleyen şairlerde de benzer bir üslup görülür. A. Kadir örneğin şu dizelerinde yirminci yüzyılın gerekleriyle örtüşmeyen metafizik şiir tarzını eleştirir: "Yirminci asrın pek de aptal şairleri var; / doyurup adamakıllı karınlarını, / günde üç defa / Allah'a mektup yazıyorlar / Halbuki sizi ben, / tatlı bir duman gibi çıkaracağım yarın, / geniş ve uzun bacalarından / neşeli fabrikaların!” (alıntılayan Kahyaoğlu, 2015, s. 291). Toplumcu şiirin takipçilerinden Can Yücel (2010) ise Bir Siyasinin Şiirleri adlı kitabıyla siyasi/eleştirel şiirin üst düzey örneklerinden birini verir. Bu kitaptaki şiirlerin çoğunda siyasi taşlama havası vardır: “Komünizm elektriklendirilmiş Sosyalizmdir, / Demişti Lenin. / Bu târife ârif oldukları için mi acep / Karışık ism-i fâil birtakım örgütlerin / Yakaladıkları yerde, şu son birkaç yıldır / Sosyalistlerin organlarına elektrik vermeleri” (s. 145).

Düşünce ağırlıklı şiirler ile lirik şiirler arasındaki farkı en iyi örnekleyen şairlerden biri Sabahattin Kudret Aksal'dır. Lirik şiirlerde, şiirde konuşan kişinin seslendiği muhayyel bir varlığa sık rastlanır: William Blake (2011) örneğin sık başvurur bu nidalara: “Ah meyve yüklü güz, ve beneklenmiş" (s. 13), "Ah kış! Demirle o sert kapılarını:” (s. 14), "Ah Gül, hastasın sen!” (Blake, 1996, s. 13) örneklerinde olduğu gibi. Oysa Aksal (2014), "Şiir Üstüne Düşünce” 
şiirinde, bu romantik nidayı zihne özgü bir terimle birlikte kullanır: "Ey anlak! Ölç ve biç, düşle / Kuracağın bu sarayı / Sanrı eşittir görmekle / Geometriler ve sayı" (s. 98). "Anlak", zihin, zekâ, bellek anlamlarına gelen bir sözcüktür ve şiir kişisi kendi zihnine ölçüp biçmesini, yani düşünmesini salık vermektedir. Modern lirik şiirde, bu yüzden, romantik üsluptan farklı bir zihinsel seyir görülür. Şiir somut duyu verileriyle başlayıp ansızın bir kavramsal dizgeye oturabilir. Edip Cansever'in (1998), “Bir çıkrık bir zaman dışını kolaçan eder şöyle / İyi. Biz buna bir durumun sınırsız gelişimi diyoruz" dizelerinde (s. 110), "çıkrık”la yapılan bir mecazdan hemen sonra, teknik bir kavramsal açıklamayı andıran bir ifade gelmektedir. Şairin "Tanrım! / Taş kesilmemek için taş / Bunu evrenin sonsuzluğu diye yorumlar varlığı olmayan bir söz" (s. 112) dizelerinde de soyut ve felsefi bir üslup görülür ki buna benzer başka örnekleri Cansever'in şiirlerinde bulmak zor değildir. Devrim Dirlikyapan (2016) Cansever’in şiirlerindeki düşünsel boyutu çeşitli yönleriyle irdelemiştir. Dirlikyapan'a göre örneğin, Cansever'in Çağrılmayan Yakup adlı eserinde varoluşçu temalar vardır. Albert Camus'nün Yabancı'sı ve özellikle Franz Kafka'nın Dava'sıyla Cansever' in bu eseri arasında ortak motifler bulur Dirlikyapan (s. 121). Ona göre bu şiirde şiir kişisi bir mahkeme salonunda gibidir ve şair, "Gerçekten alışıyoruz da. Ama kimseler kendini savunamıyor ki" dizeleriyle, "yargılama sürecinin bir yaşam boyu sürdüğüne ya da yaşamın bir yargılama olduğuna, giderek buna alışıldığına" işaret etmektedir (s. 123).

Şiirde felsefi bakış açısının yanı sıra poetik duruşların dile getirilmesine de sık rastlanır. Şairler düzyazı ve söyleşilerinde dile getirdikleri görüşleri, bir de şiirle ifade edebilirler. Behçet Necatigil'in (2013) "Kurar yeni barınak kullanıp aynı taşları” dizesi (s. 331) şairin gelenek ile modernlik arasında kurduğu dengenin bir özetidir ki bu şekilde de yorumlanmıştır (Kalpaklı, 2010, s. 32). Şairin "Bütün diri spermalar, şiirler / Kalsın yerli yerinde, / Tavlı topraklara değil de / Kuru tahtalara düşecekse" dizeleri ile (Necatigil, 2013, s. 315) "Şiir kontrol hap1 almayan şairlerden korkunuz!” (s. 1237) özdeyişi arasında tam bir fikir birliği vardır. Poetik anlayışın şiire dönüşmesine Hilmi Yavuz'un şiirlerinde de rastlanır. Şairin “Yolculuk ve Şiir” şiiri bunun çarpıcı örneklerinden biridir. Yavuz bu şiirinde, eleştirel denemelerinde sık sık yer verdiği Michael Riffaterre'in "matris" kavramını şiirleştirir: "Her şiir bir şiiri örter ve gizler; / görülsün istemez 'gül' veya 'hüzün'...” (Yavuz, 2006, s. 364) dizeleri Riffaterre'in kuramsal metin okuma yönteminin bir anlatımıdır. Şiirde bir söz veya söz öbeği şiirin matrisidir ama bu matris metnin yüzeyinde görülmez ancak bir okuma yöntemiyle ortaya çıkarılabilir (Yavuz, 2005, s. 293).

Görüldüğü üzere, Türk şiirinin çeşitli dönemlerinde, siyasi, felsefi veya poetik bağlamda, çeşitli üsluplar altında, zihinsel yönü ağır basan şiirlere rastlanır. Kuşkusuz bu yazıda bütün bu örnekleri derlemek olası değildir ama hiç değilse bir örneklem sunulabilir; bu yazının okuruna bu şiirlerin yaygınlığ 1 gösterilebilir. Bu şiirlerde ana hedef ses ve imge değildir, daha çok bir fikrin şiir biçiminde ifade edilmesidir. Bu şiirlerde düşünce ögesi arka plana itilmemiştir; daha çok şair, vurgulamak istediği fikir üzerinde okurun yoğunlaşmasını arzu etmektedir. 


\section{Modern Batı Şiirinde Düşünce İzleri ve İki Kavram}

Şairlerin bir akıl insanı olarak görülmedikleri yaygın bir görüştür. Avrupa edebiyatında bu görüşün izleri Platon'un İon diyaloğuna dek izlenebilir ve yankıları hâlen sürmektedir. Platon, şiirin bir akıl ürünü değil, bir ilham ürünü olduğunu savunur çünkü şairler kendi sanatlarının teknik bilgisine sahip değildir; bilgiyle değil, ilhamla şiir söylerler:

Kahramanlık şiirlerini yazmış büyük şairlerin, duygu şiirlerini yaratmış büyük şairlerin o güzel şiirleri, sanatın değil, insanın yüreğine, benliğine üflenmiş tanrısal bir nefesin ürünleridirler. Kozibantlar nasıl ancak kendilerinden geçtikten sonra dans edebilirlerse, duygu şairleri de bildiğimiz o güzel eserleri yaratırken kendilerinde değillerdir, musiki ve ahengin akıntısına kapılmış, onların malı olmuşlardır, akılları başlarında iken değil ama, kendilerini kaptırınca ırmaklardan süt akıtan, bal akıtan Bakkhalara benzerler. Lirik şairlerin ruhunu elinde tutan aynı çılgınlıktır ki bunu zaten kendileri söylerler. (Platon, 2011, s. 267)

İlham, Platon için değer düşürücü bir şeydir. Çünkü onun amacı bir şiir kuramı ortaya koymak değildi. O daha çok bir bilgi kuramı inşa etmek istiyordu ve felsefeyi şiirin hükümranlığından çekip çıkarmak, bir soyut düşünme sanatı hâline getirmek istiyordu. Bu nedenle bir duygu varlığı olarak gördüğü şairleri hedefe oturtmuştu. Şiirde akıl ve duygu karşıtlığının nedenleri arasında, Platon'un bu şiir-dış1 görüşleri büyük bir yer tutmaktadır. Ancak Platon’un bu görüşleri, zaman zaman, kendi çizdiği haritanın dışına çıkarılmış, tersine çevrilmiştir. Longinus (M. S. 1. yüzyıl) örneğin, şairin ilhamla yazdığını onaylar ama bu nedenle onun değerini düşürmek şöyle dursun, ona büyük bir yetke ve otorite bahşeder. Longinus'un görüşleri şairleri bir deha olarak görme geleneğinin köşe taşlarından biridir ve bu hâliyle şairi yücelten Romantizm'in erken habercilerinden biri olarak görülür (Leitch, 2010, s. 135). Yücelik Üzerine (Peri Hupsous) adıyla bilinen eserinde, sanatta yüceliğin kaynağını “duygu” ya (pathos) dayandırır Longinus. Ona göre bir sanat eseri karşısında insanın soluksuz kalıp vecde sürüklenmesi ancak o eseri yaratanın zihninde "soylu duygular"ın olmasıyla mümkündür: "Yücelik, soylu bir zihnin yankısıdır” (s. 139).

Şairin bir deha olarak görülmesi, akılla duygunun ayrılıp şiirin oluşumunda duygulara öncelik verilmesi, Romantik şiir düşüncesinin taşıyıcı kolonlarıdır. Onlara göre, şair öteki insanlardan farklı, sıradışı bir dehadır. Yüce duygular, ilhamın etkisiyle şairin kontrolünden çıkıp taşar. Bu nedenle İngiliz romantik şair Wordsworth (2005), "Şiir, güçlü duyguların kendiliğinden taşmasıdır: Kaynağını sükûnet içinde hatırlanan ruh hâlinde bulur” (s. 251) demiştir. Romantik şiirde, duyguların taşması, edebiyat ve felsefede bir dönüşümü gösteren bir imgedir aslında. Romantik akıma kadar, edebiyatta taklit kuramının bir ürünü olan "ayna" eğretilemeleri geçerliyken, romantik akımla birlikte "lamba" eğretilemesi geçerli olmaya başlamıştır. Çünkü zihin, romantiklere göre, kendi üzerine düşen izlenimi dışa yansıtan, edilgen bir "ayna" değildir artık; daha çok zihin, kendi iç ışığını dışarı veren bir "lamba" gibi düşünülmeliydi (Abrams, 1971, s. 57-58). 
Şiirin sanatçının iç dünyasından, kontrol edilemez bir şekilde taşması, modern şiir ve eleştirisini rahatsız eden bir varsayımdı. Çünkü modern şairler yirminci yüzyılın karmaşık sorunlarıyla boğuşmaya başlamışlardı; modern eleştiriyse, eleştiri sahnesine analitik bir bakış açısı geliştirme amacında olduğundan, şairi ve duygularını mistik bir bakışla yüceltme eğilimini dışladılar. Modern eleştirmenler, şairle eser arasındaki, romantiklerin ısrarla kurmaya çalıştığı organik bağı çözmek istemişlerdi. Çünkü bir şiirin anlamı, o şiirin kaynağı olan şaire indirgendiğinde sınırlanıyor; kimi zaman o anlam doğru ve geçerli de olmuyordu. Bu nedenle, Wimsatt ve Beardsley (1954), eleştiri tarihi açısından bir dönüm noktası olarak kabul edilen "Niyetsel Hata" başlıklı yazılarında, Platon'un görüşlerini anımsatırlar. Nasıl? Sokrates 'in Savunması'nda şöyle bir bölüm vardır: Platon'un Sokrates'i, bilgi açısından şairlere duyduğu güvensizliği anlatmak için bir anekdot aktarır. Sokrates, en iyi şairlerin yanına gidip onların en iyi şiirlerinden bölümler okur ve o bölümlerde ne anlatmak istediklerini sorar ama aldığ yanıtlar karşısında hayal kırıklığına uğrar (Platon, 2011, s. 16). Wimsatt ve Beardsley, Platon'un -aşırı katı tutumuna rağmen- şairler hakkında bir gerçeği gördüğü konusunda emindirler (s. 7). Şairler eleştiri sahasında çoğu kez görüş bildirir, bu görüşler, tıpkı Wordsworth'ün şiir tanımı gibi, yaygın bir etkiye de sahip olabilir ancak bütün bu yaklaşımlar aslında sanatın alanına dahildir, eleştiri alanına değil (s. 9). Eğer bir benzetme mazur görülürse, nasıl şiir güçlü duyguların taşmasıyla oluşuyorsa, şairlerin şiir hakkındaki görüşleri de denetlenemez duygu taşkınlarının eleştiri sahasını işgal etmeleri anlamına gelebilir.

Modern şiir, tıpkı modern eleştiri gibi şairle eseri arasında kurulan organik bağları sorgular. T. S. Eliot (1934) örneğin, Wordsworth'ün "sükûnet içinde hatırlanan ruh hâli” formülünü yetersiz bulur (s. 21). Bunun nedeni, şiirin tamamen, ruh hâllerinin belli bir anda hatırlanması ve salıverilmesiyle ortaya çıkan bir sanat türü olmamasından kaynaklanır. Şiirde gelenek, yani ölmüş şairlerin yazdıkları, ruh hâlleri kadar etkilidir ve olgun bir şair, şiirini, bütün bu karmaşık toplamdan çıkarır (s. 15). Eliot, bu görüşünü savunmak için bir katalizör örneği verir. Oksijen ve kükürtdioksit bir platin filamentinin bulunduğu bir ortamda birleştirilirse sülfürik asit ortaya çıkar ama meydana gelen bu asitte platin filamentinin izine rastlanmaz. Üstelik platin filamenti de bu reaksiyondan etkilenmez. Eliot, şairin zihnini, işte bu platin filamentine benzetir. Yani çeşitli ruh hâlleri, duygular ve gelenekten gelen etkiler, bir reaksiyona uğrar ve bunlardan yeni bir madde olarak, şiir ortaya çıkar. Şair ne kadar olgunsa, özel yaşantısı ile yaratıcı zihni arasındaki mesafe, o denli artacaktır (s. 18). Görüldüğü üzere Eliot, kendi şiirsel görüşünü anlatırken, doğrudan romantizmin temel görüşlerinden birini, Wordsworth'ün şiir tanımını çürütmektedir. Şiirde basit ve kişiselleştirilmiş duyguculuğun bir eleştirisidir bu ama Eliot şiirde akıl, zekâ ve nükteyi, "Metafizik Şairler” başlıklı yazısında işler. Bu yazısında Eliot, Avrupa şiirinde on yedinci yüzyıldan itibaren düşünce ile duygunun birbirinden kopmasından yakınır. "Duyarlılık bölünmesi”" (dissociation of sensibility) olarak ifade ettiği bu ayrışma, John Donne, Andrew Marvell, Abraham Cowley vb. şairlerde yoktur. Duyarlılık bütünlüğü ile ayrışması arasındaki fark, Eliot'a göre, şairler arasında var olan basit bir derece farkı değildir. Ona göre bir zihniyet dönüşümü yaşanmış ve düşünce ile akıl arasındaki sıkı bağlantı kopmuştur. Bu nedenle Eliot için John Donne, modern şiir için olumlu bir örnektir, çünkü 
onun şiirlerinde düşünce ve duygu iç içedir. Bu konuyu en iyi ifade eden araştırmacılardan biri, Mina Urgan'dır (2008). Şöyle söylüyor:

Edebiyat alanında uzun süre herkesçe benimsenen inanca göre, insan, heyecanları ve tutkularıyla duyar, kafası ve aklıyla da düşünürdü. İnsanın aynı anda hem duyması, hem düşünmesi olanaksız sayılırdı. Çok derine kök salmış olan bu yanılgıya göre, düzyazı yazarken düşünmek gerekirdi; ama şiir yazarken, özellikle aşk şiiri yazarken, akıl işin içine karıştırılmaz, ancak duygularla yazılırdı aşk şiirleri. Donne ise, bunun aksini kanıtladı. Çünkü çok yoğun ve coşkulu olan tutkularından yararlandığı gibi, o bilgili ve çapraşık dimağından da yararlandı aşk şiirlerinde. Yüreğiyle duyduklarını en küçük ayrıntılarına kadar dimağıyla incelerken, bir yandan da, T. S. Eliot'ın açıkladığı gibi, düşünceyi duymasını, düşünceyi elle dokunulabilecek kadar somutlaştırmasını bildi. Böylece Donne'ın şiirinde düşünceyle duygu, mantıkla tutku, bilgiyle hayal gücü öylesine kaynaştı ki, bunlar birbirlerinden ayırt edilmez oldu artık. (s. 179)

Düşünce ve duygu arasındaki bu birliğin takdir edilmesi, modern çağın deneyimleri bölüp parçalamasına duyulan bir tepki olarak da yorumlanabilir. Düşünce ve deneyim arasındaki bağlar koptuysa, bunu yeniden birleştirecek olanlar da şairler olmalıdır. Bu konuyu anlamak için Türk şiirinde şairaneliğe duyulan tepki hatırlanabilir. Şiirin yalnızca duygularla ilgili olduğu fikri, yapay imgeler doğurabilir; şiir akılcı düşünceden, süregiden teknolojik gelişmelerden koparak klasik ve basmakalıplaşmış duyarlılıklarla yazılıyor hâle gelebilir. Orhan Veli'nin sıradan insanı şiire sokması, "nasır" sözcüğünü şiirsel bir imge olarak kullanması, Nâzım Hikmet'in endüstriyel hayatın gürültüsünü şiire dökmesi, hep düşünceden kopuk duygusal şiire bir tepki olarak görülebilir. Metafizikçi olarak adlandırılan şairler, çağlarının bilimsel gelişmelerini şiirlerine dâhil edebiliyorlardı. Örneğin Donne, iki sevgiliyi bir pergelin iki ayağına benzetir; pergelin sivri ucu sevgilisidir şairin, öteki ucu ondan ne kadar uzaklaşırsa uzaklaşsın, nasıl olsa pergelin çizdiği kusursuz daire onları birleştirecektir (Urgan, 2008, s. 173). En bilinen şiirlerinden olan "The Flea” da (Pire) Donne, aşkı romantiklerin tasavvur etmekte zorlanacağ bir benzetmeyle şiire döker. Kendisiyle birleşmeye yanaşmayan sevgilisiyle, kimyevi bir deneyi andıran bir benzetmeyle alay eder şair. Küçücük bir pire önce kendisini, sonra da kızı ısırmış ve ikisinin kanı pirenin gövdesinde birleşmiştir. Kızın korumaya çalıştığı bekareti kaybolmuştur bu yolla güya. Donne, bunun hiç de bir günah, utanç veya ayıplama sayılmayacağını alaycı bir yolla anlatır. Kastettiği aslında sevişmenin kimyevi bir eylem olduğudur; kanlarımız pirenin gövdesinde kaynaşıyorsa, başka bir yolla da sıvılarımız kaynaşabilir, demektedir şair (Donne, 2006, s. 4). Eleştirmen Samuel Johnson'ın dediği gibi, “en uzlaşmaz düşünceler”, “çılgınca bir araya getirilir” Donne'ın şiirlerinde (Leitch, 2010, s. 387). Deneyimlerin bu şekilde birleştirilmesi, Donne'ı modern şiire özgü duyarlılığa yaklaştıran şeydir. Bunun en çarpıcı örneklerinden biri, Urgan'ın (2008) şu tespitidir: 'XX. yüzyılın en önemli romancılarından Virginia Woolf'un belirttiği gibi, çelişkileri ve karmaşıklığı yüzünden, Donne bize bir XVII. yüzyıl şairi değil, çağdaş bir şair izlenimi verir” (s. 169). İşte bu nükteci tavır, şiirde aşırı duygusallığın ve coşkulu lirizmin karşısına aklı ve zekâyı çıkarır. 
Romantik şairaneliğin modernist şiir eleştirisi tarafından yıkıma uğratılmasında, Ezra Pound'un, ilk kez, Mina Loy ve Marianne Moore adlı modernist şairlerin şiirlerini ele alan bir yazısında kullandığ 1 bir kavram da önemli bir yere sahiptir. Bu kavram, logopoeia'dır. Türkçeye "akıl ürünü” olarak çevrilebilecek bu kavramı Pound, şiirde "ses” (melopoeia), ve "imge" (phanopoeia) dışında kalan bir "dil”" alanını işaret etmek için kullanır. Ona göre logopoeia, "zihnin, sözcükler ve fikirler arasındaki dansıdır” (Pound, 1973, s. 424). Loy ve Moore, Pound'a göre, lirik şiir meraklılarının safdilane denecek ölçüde aşırı duygusallıklarından ya da doğayı bir sığınak olarak görmelerinden rahatsızdır. Bu şairler, uçurumun kenarında gezinen, çaresizlik içindeki zeki insanların şiirinin peşindedir. Onların şiirlerinde "kalbin çığlığı” yerine, "zihnin çığlığı” işitilir. Bu da onların açıkça romantizm ve lirizm karşıtı bir şiir yazdıkları anlamına gelir. Zaten antolojilerde, Loy’un şiir dilinin satirist ve deneysel olduğu, lirik olmadığı vurgulanır: "Onun şiir dili soyut ve somutun tuhaf bir karışımıdır" (Ramazani vd., 2003, s. 269). Loy (2015), “'[ş]iir büyülenmiş düzyazıdır, görsel düşüncelerden oluşan bir müzik, bir fikrin sesidir” sözleriyle (s. 157) şiir anlayışındaki fikrî boyutu ortaya koymaktadır. Moore da biyoloji ve hayvan anatomisi derecesi almış bir şair olarak biyolojinin şiirine önemli bir etkisi olduğunu kabul eder. Kendisiyle yapılan bir söyleşide şunları söyler:

Laboratuar çalışmaları şiirimi etkiledi mi? Eminim ki etkilemiştir. Biyoloji derslerini, minör, majör ve histoloji, son derece heyecan verici buldum. Aslında tıp okumayı düşünmüştüm. Kesinlik, ifade ekonomisi, çıkar içermeyen gayeler için kullanılan mantık, çizmek ve tespit etmek hayal gücünü özgürleştiriyor -en azından bir miktar etkiliyor- gibi geliyor bana. (Moore, 1961).

Görüldüğü üzere, romantik duygucu şiirin karşısında, soyut ile somutu karıştıran, yoğun bir zihinsel faaliyetle yazan bu şairler, Eliot' 'n metafizikçi şairlerde gördüğü bir üslubun uzantıları, geç örnekleri gibi görülebilir. Nitekim, Eliot'ın görüşleri ile Pound'un görüşlerini birleştiren de bu noktadır. Eliot, metafizikçi şairler yazısında, Fransız şair Jules Laforgue'u Donne'ın şiir üslubuna yakın görür; Pound da, Loy ve Moore'u, Laforgue'un bilinçdışı takipçileri olarak gördüğünü öne sürer (s. 424). Bu nokta, Eliot ve Pound'un yazıları arasında görülebilecek bir kesişim noktasıdır.

Modern Avrupa ve Amerikan şiirinin kuruluşunda, Eliot ve Pound'un girişimleri hep romantik ve aşırı duygucu lirizme, benliğin denetimsiz dışa vurumuna ve çocuksu şairaneliğe karşı olmuştur, denebilir. Benliğin duygusal dışa vurumu yerine, evrene ve insana araştırıcı ve nesnel bir bakışla yönelen zekânın şiirini yazmak istemişlerdir. Modern Türk şiirinde de, birebir olmasa da, aşırı duygucu ve şairane tabiatın yerine, zihinsel üslubun devrede olduğu şiirlere rastlanır.

\section{Zihinsel Şiirin İzinde: Melih Cevdet Anday ve Özdemir Asaf'ta Akıl Oyunları}

Modern Türk şiirine bu gözle bakıldığında, pek çok şairin üslubunda, şairaneliğe, aşırı duygusal lirizme karşıt, akılcı, eleştirel, paradokslarla örülü, nükteci bir yön bulunduğu görülebilir. Bu şairlerin şiirlerini okurken, sözcüklerin tınısına veya görsel imgelerin çarpıcılığına 
kapılıp anlamı görmezden gelemeyiz. Bu şairler daha çok aklımızı işletmemizi, Pound'un deyişiyle, sözcükler ve fikirler arasında dans eden bir zihne tanık olmamızı ister. Şiir salt bir duygu ürünü olarak algılandığında, okur, sözcüklerden yayılan havanın akışına uyup bir vecd hâline kapılabilir ama Anday ve Âsaf gibi şairlerin eserlerinde okur, olabildiğince uyanık kalıp şiirde olan biteni fark etmelidir.

Anday'ın şiirlerindeki düşünce ve akıl vurgusunu kavramak için öncelikle şiirin zihinsel bir sanat dalı olduğunu kabul etmek gerekir. Dahası, şiirin de bir zihinsel faaliyet olduğunu, algıların ve duyguların, akıl yürütme işleminden koparılamayacağını da onaylamak gerekir. Niçin? Çünkü, Anday, mantıksal olmayan olguların da akıl içinde yer aldığını, aklın, algılanmış duyulardan, duygulardan başka bir şey olmadığını düşünür (aktaran Kahraman, 1995, s. 41). Bu vurgu önemlidir; çünkü şiire bilişsel anlamda yaklaşan düşünürlerin görüşü de bu yöndedir: "Şiir, düşünmedir. Bu yüzden şiir, söz-öncesi, akıl-öncesi, mantık-öncesi değildir. Algılar ve duygular, res cogitans'a düşman veya rakip olmadıkları hâlde, oradadırlar" (Dubreuil, 2015, s. 68). İkinci olarak Anday’ın şiirlerinde, Hasan Bülent Kahraman'ın (1994) vurguladığı üzere, doğayı ve onun ürettiği verili duygusal ilişkileri tanımayı reddeden bir tavır vardır. Kahraman’a göre Anday, var olan dünya ve onun ilişkileri yerine, bambaşka yeni bir düzen önerisinde bulunmaktadır. Bu nedenle Anday'ın şiirinde, genel geçer okurun aradığı duygusallığı bulmak olanaksızdır. Şöyle söylüyor:

Anday’ın şiirinde bizim alıştığımız duygusallık, duygululuk yoktur. Olamaz da; çünkü, o duygusallık bizim verili dünyayla kurduğumuz bilinen ilişkimizin bir sonucudur. Oysa Anday yeni bir dünya tanımladığı zaman ortaya yeni bir duygusallık katmanı çıkacaktır. Bu da son derecede doğaldır. Çünkü, duygularımız değişik zaman ve uzamda değişik özellikler gösterecektir. Dünyayı algılayan ve dönüştüren bir bilincin nesneye ve kurduğu düzene yönelik, hatta onlardan kaynaklanan yeni bir duygulanımı olacaktır. Eşyayı ve ilişkileri o duyarlılıkla tanıyacaktır. Anday’da var olan budur. Olmayansa, dediğim gibi psikolojizmdir. (s. 44)

Verili dünyanın reddedilip yenisinin önerilmesi, aslında avangart bir tutumdur ve Anday'ın da dahil olduğu "Garip" akımının manifestosuna uygun bir tutum olarak görülebilir. Orhan Veli (2013) “Garip” önsözünde, Paul Eluard'ın, "Bir gün gelecek, o; sadece kafa ile okunacak, edebiyat da böyle yeni bir hayata kavuşacak" dediğini aktarır (s. 26). Bu da gösterir ki modern şiirin, geleneksel imgelere, şairane olarak tabir edilen romantik duyguculuğa karşı duruşuyla, “Garip” akımının veya Anday’ın kendine özgü akılcılığı arasında bir uyum vardır.

Ancak “Garip" akımında olmayan bir şey de vardır Anday’ın poetikasında. Şiirde mitlere, metinlerarasılıklara yönelme, Eliot, Pound vb. modernist şairlerin sık başvurdukları bir yöntemdir ve Anday da (1997) Kolları Bağlı Odysseus'un sonuna eklediği “Kitaba Ek" yazısında, bu iki şairin kullandığı yöntemi denediğini belirtmiştir (s. 174-176). Bu eserinde Anday, doğanın metafizik alımlanışının ötesine geçip akılcı bir dünyanın imgesini kurmaya çalışır. Mitleri de şiirlerinin yapı taşı hâline getirir Anday ama artık mitlerden arındırılmış bir dünyada olduğunun farkındadır. Aradaki fark şöyle ifade edilebilir: Doğanın mitik bir şekilde 
algılandığı bir dünyada yaşayan insanın mitlerle olan ilişkisi ile mitlerin işlevinin yittiği, bilim ve teknolojinin egemen olduğu bir çağda yaşayan insanın mitlerle ilişkisi arasında, keskin bir fark vardır. Anday modern bilim çağının bir şairi olarak mitik dili keşfetmeye çalışıyor, onun imkânlarını araştırıyor olabilir ama bunu yaparken de aklını kullanmakta, akıl yürütmektedir.

Mehmet Kaplan'ın (2005) Anday'ın şiirlerindeki akılcı tutumu irdelerken, şiiri sezgi ve mitlerle özdeşleştirmesi nedeniyle, Anday’ın kuru akılcılığa yenik düşebileceğine dikkat çekmesi önemlidir. Aynı yazıda Kaplan, materyalizmi öne çıkarmış olsa da, Anday’ın şiirlerinde mitlere başvurmasını olumlu bir nokta olarak gösterir. Çünkü mitler, şiirin kaynaklandığı bir kök, âdeta şiirin ilksel biçimi olduğundan, materyalizmi savunan bir şairin şiirlerinde mitlerin yer bulması, idealizmin bir başka kapıdan şiire girmesi anlamı taşıyabilir. Kaplan (2005) şöyle ifade eder:

Kolları Bağlı Odiseus, bütün olarak tabiata ve tabiatın insanoğluna yüzyıllar boyunca telkin ettiği esrarlı duygu ve hayallere karşı aklın zaferini anlatan bir eserdir. On dokuzuncu yüzyıl materyalizmine ve marksizme dayanan, insan ruhunu maddeye irca eden bu tezi, bugün ilmî olarak müdafaa etmeğe imkân yoktur. Yirminci yüzyıl batı felsefe ve psikolojisine hâkim olan görüş odur ki, eski dinler ve mitolojilerle beraber modern ideolojiler ve kâinat tasavvurları da mahiyeti izah edilemeyen insan ruhunun "inşa”"larından ibarettir. C. G. Jung, mücerret fikirlerin "archétype”lerin işlenmiş şekilleri olduğunu söyler. İnsanoğlunun düşüncelerini idare eden "kollektif gayrişuur”, daima yeni hayaller ve tasavvurlar yaratır. Kâinatı maddî olarak izaha çalışan ve "us"unu yücelten şairin, eserinde, insanlığın eski "archétype”lerini ve mitlerini kullanması, büyük psikologun haklı olduğunu gösteriyor.

Melih Cevdet Anday, materyalist görüşü bir yana bırakılırsa, Kolları Bağlı Odiseus'unda mücerret düşünceyi terkederek, insanlığın ebedî şiir hazinesi olan sembollere ve mitlere gitmekle iyi etmiştir. Bu suretle o, kendisini ve okuyucularını aklın kuru formüllerinden kurtarmıştır. (s. 140)

Şiirin ses ve imgeyle birlikte, mitlerle olan bağlantısı, okura alıştığı bir poetik formül vermektedir. Günümüzde de bir şiir okurken, geleneksel imgeleri, mitik, simgesel ifadeleri fark eden okur, şiirsel bir haz duyar. Mehmet H. Doğan (2004) bu nedenle Anday'ın ilkçağ mitoslarını bahane ederek, bir bilim insanı gibi, gördüklerini sorgulayarak yazan bir şair olduğunu savunur (s. 70). Doğan'ın bu yazısına verdiği isim de anlamlıdır: “İmgeden Akla Giden Yol”. Öyle anlaşılıyor ki Doğan, şiirin tarihinin imgeden akla doğru yol aldığını düşünmektedir ki bu açıdan bakılırsa Anday, doğru yoldadır. Pound'un logopoeia kavramı, işte bu nedenle modern şiirde salt ses ve imge gibi somut duyusal ögelerle yetinilemeyeceğini gösteren bir kavram olarak devreye girmektedir. Bu bakış açısının tedirgin edici noktaları yok değildir. Bunların başında akılcı bir şiirin estetik değerini yitireceği, şiir olmaktan çıkacağı düşüncesi gelmektedir. Yalçın Armağan (2004) Anday’ın “zaman” şiirini irdelediği bir yazısında, Anday’ın şiirlerine "düşünce metni” olarak yaklaşılmasından endişe duyduğunu belirtir (s. 62). Felsefeci-şair gibi alımlandığında, Anday’ın artık bir "şair” olarak görülmeyeceği endişesi, haklı bir endişedir. Benzer bir endişeyi Temizyürek (2021) de dile getirir. Ona göre mitos / logos ayrışması, 
günümüze dek taşınan bir “parçalı miras”tır ama şairler mitik dili hep zinde tutmaya uğraşır. Temizyürek'e göre Anday, her ne kadar "logos"a vurgu yapsa da, mitik çağların geçip gittiği bir dönemde mitik aklı derinden kavramış bir şairdir. İşte bu nedenle, "şiir” tanımı, "ses" ve "imge" ile birlikte şiirin kökeni olarak algılanan mitik düşünce bağlamından çıkarılıp zihinsel ve akılcı bir anlama da kavuşturulursa, o zaman bir düşünce şairi olmak, modern şiir kuramı başlığı altında irdelenebilecek poetik bir sorun olarak yeniden tanımlanabilir. Zaten Anday da (2017), felsefe ile şiir arasındaki açmazın farkındadır: "Felsefe sorunlarını ele almaktan ise, felsefe çıkmadığı gibi, şiir de çıkmaz. Sanatçı filosof değil, düşünürdür” (s. 280). Yani şiirle felsefe yapılmaz ama şiirin kendisi bir düşünce eylemi olabilir fikri çıkarılabilir bu sözlerden. Belki de bu nedenle Tahsin Yücel (2004) şöyle söylemektedir Anday’ın şiirlerini yorumlarken: "Kuşkusuz, neredeyse bütün yorumcuların söylediği gibi, Melih Cevdet Anday bir düşünce şiiri sunar bize, düşüncenin ozanıdır, ama her şeyden önce bir ozandır” (s. 128).

Şiirin zihinsel bir eylem olması, duyguların bastırılması anlamına gelir mi? Duygu şiiri genellikle lirik olarak adlandırılır. Lirik şiir kavramı, lirle çalınıp söylenen şarkılardan türemiştir ve bu nedenle hep onun "ses"le ilişkili olduğu vurgulanır (Cuddon, 1999, s. 481). Ancak lirizm, romantik duyguculukla da hep ilişkilendirildiği için -Wordsworth ve Coleridge'ın şiirlerinden oluşan derlemenin adının Lyrical Ballads olduğu hatırlanabilir burada- düşünce şiiri ile lirizmi yan yana getirmek pek olası değildir. Şiiri evren, doğa ve insan hakkında düşünmenin doğal yollarından biri olarak gören Anday'ın, “Lirisme” gibi bir şiir yazarak, lirik tavrın egemenliğini sarsma çabası şaşırtıcı değildir. Tabii bu avangart çıkışı irdelerken Anday’ın lirizmi nasıl gördüğünü de hesaba katmak gerekebilir. Önce şiirine bakalım şairin: "Lirism her şeyden önce lirism / Maddeden tarihten İsa'dan önce / Soldan önce, sağdan önce / Aç karnına bolca lirism" (Anday, 1997, s. 59). Bu şiirde Anday, lirik tutum yüzünden tarihsel ve siyasal perspektifini yitiren bir insanın portresini çizmektedir. Bu şiirine rağmen Anday (1990), lirik şiiri, "şairin kendi ağzından konuştuğu şiir" olarak tanımladığı için lirik şiirin düşünce şiirine karşıt olmadığını söyler: "Kendi ağzından konuşan şair, düşünsel olana neden yönelmesin! Ancak, eğer o kendisini her şeyden ve herkesten soyutlayarak konuşuyorsa, o zaman lirizm, benim şiirimdeki alaylı konuma girmiş demektir. Yani şair kendini kapıp koyverdi mi lirik olacak, ne dediğine, nasıl dediğine dikkat edince ise 'düşünsel' nitemini hak edecek... Yanlış buradadır” (s. 40). Ama Anday’ın bu konuda tam olarak ne düşündüğünü bir başka soruya verdiği yanıttan anlarız. Şiirlerinde düşünselliğin artmasıyla birlikte, "kuru bir şiire kayma" tehlikesinden söz açıldığında Anday, şiirde duygu ve düşünceden ne anladığını apaçık bir şekilde dile getirir:

Şiirimi beğenmeyenlere karşı benim ne diyeceğim olabilir ki! Yahya Kemal, “düşünceyi yoğurup duygu haline getirmek” demişti. Anlamıyor değilim. Ama ben daha ileri gidip, “düşüncenin duygululuğu”ndan söz etmek isterdim. Ben belki de duyguculuğa bir tepkiyimdir. Toplumumuzda düşüncenin çok az yer tutmasından mıdır, kim bilir! Tanıyabildiğim çağdaş yabancı şairlerden hiçbirinde şairane duygusallıkla karşılaşmadım. Sizin kullandığınız sözcükle, "kuru” idiler. Şair kupkuru olmalı ki, okur ondan duygular çıkarabilsin. (s. 41) 
Bu sözler, Eliot'ın (1934) “Şiir duyguları ortaya dökmek değil, duygulardan bir kaçıştır, şahsiyetin dışa vurulması değil, şahsiyetten bir kaçıştır” (s. 21) sözlerinin bir yankısı gibidir. Anday, Koçak'la yaptığı bir söyleşide (1989), Yanyana ve Kolları Bağlı Odysseus'tan sonra, "anlamı ve mantığı sorunlaştıran” bir şiir yazdığını kabul eder ama bu tutumun şiiri felsefeleştirmek anlamına gelmediğini de ekler. Ona göre, duyguları öne çıkaran bir şiirin yanında, "ussal yeteneğimizi çalıştırma yolu ile de şiirsel bir doyuma erilebileceği olasılığını" okura tanıtmak gerekmektedir (s. 84). Gerçekten de Anday duygularını bastırarak yazdığı izlenimini vermektedir ki Koçak bu sorunu psikanalitik bir çözümlemeyle ortaya koyar. Koçak, Anday'ın şiirlerindeki akılcı, aydınlanmacı üslubun, şairin yaşadığı yoğun duygusal şiddeti dindirme, seyreltme amacı taşıyor olabileceğini öne sürer. Duygular o kadar yoğundur ki onlar dışa vurulmak yerine bastırılmakta, duygular yerine, analitik düşünce öne çıkarılmaktadır. Freud'un "duygu" (affekt) ile "fikir, tasavvur, temsil veya resim" olarak tercüme edilebilecek "vorstellung" kavramları arasında yaptığı ayrımdan yola çıkıyor Koçak:

Histerik semptomun (mesela hayali ama yine de şiddetli bir "böbrek ağrısının") kökeninde travmatik bir olay yatıyordur; eğer travmanın yol açtığı duygulanım boşaltılmamışsa, bastırılmış ya da "boğulmuşsa", bu olayın belleğe kaydolan anısı da (fikir, resim, gösteren) bir 'sabitlenme' noktası haline gelecek, dürtünün marazi çekirdeğini oluşturacaktır. Freud’un bu gözlemden çıkardığı sonuçlardan biri, duyguyla resmin, enerjiyle fikrin birbirinden ayrılabileceği, farklı yollar izleyebileceğidir. (s. 33)

Koçak, Freud'un rahatsızlık uyandıran duyguyla onun temsilini birbirinden ayırma işlevinin semantik, dilsel sonuçları da olması gerektiğini belirtip Anday’ın şiirinde duyguyla fikrin kopuşuna ilişkin izler aramaya başlar. Anday'ın şiirlerinde görülebilecek bir çözme, çözülme, bağsızlaştırma eğilimi, belli duyguları seyreltme veya onları bastırma eğiliminin bir parçası olabilir. Huzursuz edici duygulanımlar, ötelenir, görünmez kılınır. Öyle ki bir "duygu korkusu" bile ortaya çıkabilir kişide. Freud'un değil ama onu izleyen bazı psikologların duygu korkusu üzerine eğildiğini belirtiyor Koçak: Pek çok analist duygu ve düşüncelere yönelik bu duygu korkusunu işlemiştir ki bunlardan biri, Melanie Klein'dır. Klein, "Bazı Şizoid Mekanizmalar Üzerine" (1946) başlıklı makalesinde "şizoid hastaları tepkisiz kılan duygu eksikliği”nden söz etmektedir (s. 36). Bu kişilerin esas meselesi kaygı bozukluğudur, onlar aslında ruhsal ağrıdan kaçınmaktadır; başka bir deyişıle, savunma mekanizması duygu izlerini seyrelterek, onu konu dışına iterek bir ruhsal ağrının ortaya çıkmasını, ortalığı yıkıp dökmesini önlemeye çalışıyordur. Öyle anlaşılıyor ki Anday’ın akılcı şiir üslubunu bu türden bir ruhsal savunma mekanizmasına bağlamaktadır Koçak: “'Akıl, 'Aydınlanma', 'hesaplama' — bunlar Anday’da bir ağrının seyreltilmesinin, 'dilinmesinin', bölüştürülmesinin aracıydı daha çok” (s. 38). Tipk1 Behçet Necatigil'in (2013) bir şiirinde söylediği gibi: “Çıt yok bellekte / Acı anıları ilerlere kaçırmıştır / Çocuklarını kurtaran bir anne gibi” (s. 679).

Şimdi akla şu soru geliyor: Duygular bastırılınca, aşırı duygucu lirizmden ve şahsiyeti ortaya dökmekten kaçılınca, nasıl bir şiir ortaya çıkacaktır? Bunun olası yanıtlarından birini Kolları 
Bağll Odysseus'taki bazı parçalarda buluruz. Bu parçalar, Anday'ın şiirlerindeki somutu soyut olarak algılama veya somut olguların kavramsal karşılığını çizmek olarak tanımlanabilecek bir özellik taşır. Romantik bir şair doğaya baktığında, uygarlığın karmaşık ve insan ruhunu bozan gürültülü dünyasından kaçılıp sığınılacak bir ana kucağı görür. Oysa Anday (1997) doğanın yüce biçimini algıladığı gibi onun kavramsal ve soyut karşılığını da görmeyi dener: "Us iki akımlıdır. Ben doğayı / Nesneleştirdim ve sayılarını / Buldum. Şimdi ne olacak idiyse / Her şey onun zoru içindedir” (s. 159). Tıpkı Aksal gibi Anday da bilincine sanki o bir başka özneymiş gibi seslenir "Ey bilinç! Sevgim de, hüznüm de / Eski bir zamandan gelmedir / Şimdi saltanatımda yapayalnızım” (s. 159). İşte bu nedenle Kaplan (2005) Anday’ın bu eseriyle doğadan kopup bir akıl varlığı hâline gelmiş insanın şiirini yazdığını düşünür. Anday’ın (1997) soyutlamacı üslubuyla bilinen Wallace Stevens'ın "This is the mythology of modern death" (Modern ölümün mitolojisidir bu) (s. 165) dizesine atıf yapması da bu açıdan yorumlanmalıdır ona göre: “İnsanın akıl vasıtasıyla tabiattan ayrılması, tabiatın 'nesneleşmesi', yani ölmesi demektir. Modern ölümün mitolojisi işte budur” (s. 139). Gerçekten de Anday doğanın somut görünümlerini bir kenara bırakıp onu zihinsel bir öz hâline getirmeyi dener; Halman'ın (2008) Stevens'ın şiiri için söylediği gibi, yaşantının kendisi yerine, onun soyut özünü vermeye çalışıyor olabilir Anday (s. 199). ${ }^{1}$ Bu öz doğanın bir soyutlamasıdır, yani matematiktir:
Bulut bir biçim değildir artık, bir
Tasarı, bir entr'acte, bir istektir;
Olumsuz bir tanımdır gökyüzü
Boyuna ilkel ve matematiksiz
Sıkar durur tanrıları boş yere...
Çünkü eski bahçelerde değiliz
Eskidendi elmanın ağaçtan düştüğü
Şimdi yalnız $1 / 2 \mathrm{gt}^{2}$
Kapsar yıldız kaymalarını
Ayıklamalı evren görütünü
Usa uygun bir düzene koymalı (s. 160)

İnsan antik çağlarda ya mitlerin içindedir ya da sadece doğayı yanı başında bir başka varlık olarak algılar; daha sonra giderek onu romantikleştirir; sonra da doğa kişinin huzur bulduğu veya dönüştürüp malı kıldığı bir uzam hâline gelir. Oysa Anday doğanın çeşitli insanî kullanımlarının ötesine geçip onun tâbi olduğu dili, matematik dilini şiire taşıyor. "Duyular" olsa olsa "eski ağaçlardır" artık (s. 148) ama "us" somut duyu verileri yerine akıl yürütme, kavramsallaştırma, nesneleri sayılara dökerek anlamlandırma işini görür. Çünkü insan büyümüştür: "Büyüdük çocukluğumuzdan / Büyüdük tarihe usulca" (s. 149). Şair, elmanın yere düşmesi eski bir tanımlamadır artık, onun özü, yani serbest düşme formülüdür $\left(1 / 2 g t^{2}\right)$ şimdi geçerli olan demektedir. Burada iki uçlu bir anlam evrenini fark etmek zor değildir. Bir tarafta, doğanın yüce ve mitik görünümünden kopup derin bir yabancılaşmaya sürüklenmek;

1 Wallace Stevens'ın şiirlerinin 2017 yılında yayımlanan bir çevirisi üzerine kaleme alınan kapsamlı bir kitap tanıtma yazısı için bk. Nilay Özer. https://t24.com.tr/k24/yazi/wallace-stevens, 1373 
öte taraftan doğanın romantik imgelemi kışkırtıcı, aldatıcı görkemini aşıp onun asıl dilini, matematiği bulmanın gönencini yaşamak. Hangi açıdan bakılırsa bakılsın Anday, modern şiire özgü bir sorgulamanın, bir yeniden yorumlamanın şiirini yazmaktadır ki bu şiirin bir logopoeia şiiri olduğunu söylemek yanlış olmaz.

Akıl ve düşünce, Özdemir Asaf'ın (2011) şiirlerinde de ana motiftir. Şair, "Poetika” başlıklı şiirinde bunu açıkça ifade eder: "Bana düşünmek vardı, payıma onu aldım, / İşledim de işledim bir hüner-işi gibi” (s. 228). Asaf da duygucu ve şairane bir şiir üslubundan kaçınır; bunun yerine eleştirel, ironik, sorgulayıcı bir şiir dili kurar. Tıpkı Anday gibi Asaf da duygularını bastırır veya öteye kaçırır; aşkı irdelerken şairane bir üslubu tercih etmez, onun yerine zekâ dolu dil oyunları yapar, paradokslara başvurur. Tıpkı Anday gibi Asaf da duyguları dağıtır, görünmez kılar. Gerilerde bir yerde, Asaf'ın yoğun bir duygusallık yaşadığı hissedilir ama şair bunları bastırır veya öteler, konu dışına iter. Tıpkı Anday gibi Asaf da duyguları serbest bir şekilde dışa vurmak yerine, onları akılla dengeler, çözümler, onlardan yeni fikirler çıkarır. Murat Belge (2018), Asaf'ın şiirlerindeki bu üslubu, yukarıda kısaca sözü edilen on yedinci yüzyıl İngiliz metafizikçi şairlerin üslubuna benzetir:

Özdemir Asaf' ın rasyonalist zihin yapısıyla aşk şiiri yazarken dahi, duygusallıklara girmek istemediği anlaşılıyor. Onun için Özdemir Asaf "karşı kutba" gidiyor, matematik ve geometriye. Aşkı, aşkın verdiği tamamlanma duygusunu dile getirmek üzere matematiğin duygudan tam arınmış terminolojisinden terimler alıyor ve bunlarla $a s ̧ k ı$ anlatıyor.

17. yüzyılın İngiliz "Metafizik” (diye tanınan) şairlerini akla getiren bir teknik. Hemen John Donne'1, Andrew Marvell'1 akla getiriyor. Türk edebiyatında hiç bilinen, alışık olunan bir durum değil. Onlar, doğa bilimlerinin gelişmesiyle derinden değişen yeni dünyada böyle bir "duygu / düşünce” dengesi kurmanın gereğini duymuşlar, yollarını aramışlardı. Özdemir Asaf da böyle bir etki hissetse bile, sanırım onunki daha kişisel düzeyde ve çerçevede bir durum: "denetimsiz duygu"dan hiç hoşlanmıyor Özdemir Asaf. (s. 368)

Özdemir Asaf'ın (2011) şiirleri arasında Belge'nin bu benzetmesini tam olarak karşılayan bir şiiri vardır. Şair "Özdüşüm” şiirinde, “Ah ben hep duyguyla akıl / Kapılarını bunca yıl / Zorladım. Bir düş gerçeği / Topladım gerçek düşümde / Savaştı bu huyla akıl, / Hep kafamda ve gönlümde" (s. 261) demektedir. Onun şiiri bir anlamda "Duyguyla anlaşmış akıl”"dır (s. 261). Özdemir Asaf'ın şiirlerinde duygu, dışa vurulması gereken yoğun heyecanlar değil, çözümlenmesi gereken bir problemdir; tıpkı Anday'da olduğu gibi. "Perspectif” şiirinde örneğin, aşk, perspektif kuramıyla irdelenir: "Senin içine girdiğim zaman / Dışımda kalıyorsun. / Senin dışından sana bakınca / İçime sığmayorsun.” (s. 97). Perspektif nesnelerin boyutlarının sabit bir uzaklıktan ve bakanın bakış açısına göre sıralanmasıdır. Bir nesneye çok yaklaştığımızda, örneğin bir binanın içine girdiğimizde, o binanın tamamı artık görünmez olur. Çünkü binanın tamamı artık göz hizasında değildir. Binadan dışarı çıkıp uzaklaşıldığında ise yapının tamamı görülür ama bu kez de binanın dışındayızdır. Asaf bu basit perspektif kuralını aşk ilişkisine 
uyarlıyor, tıpkı John Donne’ın iki sevgiliyi bir pergelin iki ayağına benzetmesinde olduğu gibi. Keskin akılcı oyunlar şairin şiir adlarına da doğrudan yansımıştır; öyle ki artık sözcüklerin yerini matematik simgeleri almıştır. Bunun nedeni şairin sözcüklere olan güvensizliği olabilir. Mehmet Kaplan’a göre Özdemir Asaf, “Kelimeler... Kelimeler...” başlıklı şiirinde, sözcükler ile gerçeklik arasındaki uçurumu işler. Kaplan (2005) şöyle söylüyor: "Biz gerçeğe bizzat yaşayarak ulaşırız. Fakat onları anlatmağa kalkınca kullanıla kullanıla yıpranmış, bizim yaşantılarımıza tekabül etmeyen kelimelerle karşılaşırız” (s. 260). Öyleyse şu söylenebilir: Sözcüklerin anlatım gücüne güvenmeyen şair, sözcüklerin yanı sıra bir de matematik dilini kullanmak istemiş; sözlerine bir kesinlik etkisi vermek istemiş olabilir. Örneğin aşkın kadın ve erkeği ayrı doğalarından koparıp birleştirmesi, Özdemir Asaf (2011) için " $2=1$ ”dir: "Kim o, deme boşuna.. / Benim, ben / Öyle bir ben ki gelen kapına; / Başdan - başa sen.” (s. 73). Ama aşkın bireyin varlığını yok edici işlevi, "1=2"dir: "Sen sevgilenince / Seni tam kalbinden vurdum / Seni kestim, seni yedim" (s. 141). Matematik simgeleri, "1X2X3X4, 4X3X2X1" başlıklı şiirde, iki sevgilinin, "ben”den "sen”e, "sen”den "ben”e doğru akan duygularının denklemi olarak kullanılır. Şöyle:

Sen seni sendesin bil ise

Dinle uzaktan, dışından dinle beni..

Sen nerede yoksan, orada varsin

Ben seni bendesin bileyim ise

Dinle yakından, içinden dinle beni..

Sen benim kadarsin. (s. 137)

Bu şiirde Asaf' ’n iki insan arasındaki aşkı matematiksel bir dengeye oturtmuş olduğu görülür. Öyle ki "ben” ve "sen” in eylemleri, sayılar arasındaki bir denkliğin kesinliğine indirgenmiştir. "Sen"in kendisini kendisi olarak bilmesi, ötekini dışarıdan ve içeriden dinlemesi, hep "ben"in "sen”i dinlemesiyle eştir. Çünkü "ben" ve "sen”, şiirin başlığındaki gibi ters yönde aksalar da öz itibariyle birbirine eşittir: "Sen benim kadarsın”. Şiirin bu yönü, Asaf'ın eşitlikçi bir aşk anlayışı geliştirme arzusunu gösterebilir. İster geleneksel ister modern şiirde olsun aşk hep bir efendi / köle diyalektiğini dayatır oysa Asaf, aşkın muhatapları arasındaki ilişkiyi matematiksel bir denkliğe oturtur.

\section{SONUC}

Şiir geleneksel sanatların en eskilerinden biri olduğu için tanımı hep duyguların ifadesi bağlamında ele alınıp lirik bir role sıkıştırılmıştır. Oysa ister geleneksel ister modern olsun akıl, mantık ve eleştirel düşünce de hep şiirin bir parçası olagelmiştir. Şiirde aklın öne çıkması onun bir söyleve, didaktizme veya propaganda faaliyetlerinin bir aracına indirgendiği anlamına gelmez. Edebiyatımızın yenileşme devrinde, on dokuzuncu yüzyılın aydınlanmacı veya yergici şiirlerinde veya ideolojik yönü ağır basan eserlerde söylevci eğilimler baskın olsa bile, modern Türk şiirinde aklı egemen öge olarak kullanan, sanat yönü güçlü şiirler de ortaya çıkmıştır. Modern Batı şiirinde romantik duygusallığın şairane havası yerine, endüstri devrimi sonrası 
kent yaşamının buhranını dile getirecek, sorgulayıcı şiirlerin varlığı bilinir. Hatta modern şiirin kurucu isimlerinden T. S. Eliot ve Ezra Pound'un poetik anlayışları, romantizmin aşırı duygusal motiflerini dengelemek, entelektüel içeriğin şiire hâkim olmasını sağlamak üstüne kuruludur. Modern Türk şiirinde de klasik şairaneliğin yıkımı, Nazım Hikmet'in fütürist, dadacı şiirleri, Garip akımının ironik ve lirizm yıkıcı tavrı ile belirginleşir. Melih Cevdet Anday ve Özdemir Asaf ise duygusal içeriğe karşı aklı şiirlerinin ana ilkesi hâline getirmişler; yaşantıya özgü duygusallığın yerine eleştirel, mantıkçı bir şiir dili kurmaya çalışmışlardır. Bu şiir dili, duygusal içeriğin acı verici doğasından sıyrılmak, onun bilince ulaşmasını, dilde temsil edilip yeniden yaşanmasını önleme çabası olarak yorumlanabilir. Şiir diline matematik ve geometrik ifadelerin karıştırılması ise sözcüklere duyulan güvenin sarsılmasının bir sonucu olabilir. Her ne şekilde olursa olsun şiir dilinin, somut deneyimlerin duyumsal ifadesi olarak değil, somut deneyimlerin soyut ve kavramsal bir ifadesi olarak da iş görebileceği söylenebilir; Anday ve Asaf'ın şiirlerinde olduğu gibi.

Teşekkür: Bu makaleyi yazarken kendilerine fikir danıştığım Efe Murat Balıkçıoğlu, Selim Tezcan ve Ömer Aygün'e teşekkür ederim.

Acknowledge: I would like to thank Efe Murat Balıkçığlu, Selim Tezcan and Ömer Aygün, for whom I consulted while writing this article.

Hakem Değerlendirmesi: Dış bağımsız.

Çıkar Çatışması: Yazar çıkar çatışması bildirmemiştir.

Finansal Destek: Yazar bu çalışma için finansal destek almadığını beyan etmiştir.

Peer-review: Externally peer-reviewed.

Conflict of Interest: The author has no conflict of interest to declare.

Grant Support: The author declared that this study has received no financial support.

\section{KAYNAKÇA/REFERENCES}

Abrams, M. (1971). The mirror and the lamp. Oxford: Oxford University Press.

Ahmet Haşim. (2013). Bütün şiirleri. İstanbul: Dergâh.

Armağan, Y. (2004). Anday şiirinde zaman’1 “yok”lamak. K. Özkan ve A. Akgül (Ed.), Bütün yüzyılları yaşadım (ss. 49-66). İstanbul: Alkım.

Aksal, S. K. (2014). Ne tuhaf. İstanbul: YKY.

A. Kadir. (2015). Şiirlerim. O. Kahyaoğlu (der.), Modern türkçe şiir antolojisi 1 içinde (s. 291). İstanbul: Ayrint1.

Anday, M. C. (1990). Ben belki de duyguculuğa bir tepkiyimdir. Şair çünkü onlar. Enver Ercan, (haz). İstanbul: Kavram.

Anday, M. C. (2017). Doğa toplum ilişkisi. Yalçın Armağan (Ed.), Suçumuz edebiyat içinde (ss. 13-22). İstanbul: Everest.

Anday, M. C. (Haziran/Ekim 1989). Melih cevdet anday'la söyleşi. Defter, 10, Orhan Koçak, (haz.). (s. 81-87). 
Anday, M. C. (1997). Rahatı kaçan ăgaç. İstanbul: Adam.

Belge, M. (2018). Şairaneden şiirsele. İstanbul: İletişim.

Blake, W. (2011). Güz. Nail Bezel (haz.) Şiir perilerine: Ingiliz romantik şiirinden seçmeler içinde (s. 13). İstanbul: YKY.

Blake, W. (2011). Kış. Nail Bezel (haz.) Şiir perilerine: Ingiliz romantik şiirinden seçmeler içinde (s. 14). İstanbul: YKY.

Blake, W. Hasta gül. Hasta gül içinde (s. 13). (Dost Körpe, çev.). İstanbul: Kabalcı.

Cansever, Edip. (1998). Yerçekimli karanfil. İstanbul: Adam.

Cuddon, J. A. (1999). Dictionary of literary terms \& literary theory. Londra: Penguin.

Dağlarca, F. H. (2014). Bütün şiirleri 1. İstanbul: YKY.

Dirlikyapan, D. (2016). Ölümü gömdüm, geliyorum. İstanbul: Metis.

Doğan, M. H. (2004). İmgeden akla giden yol. K. Özkan ve A. Akgül (Ed.), Bütün yüzyılları yaşadım, (ss. 67-75). İstanbul: Alkım.

Donne, J. (2006). The flea. Metaphysical poetry (Christopher Ricks ed.). Londra: Penguin.

Dubreuil, L. (2015). On poetry and mind. Diacritics 43(1), ss. 64-80.

Eagleton, T. (2011). Şiir nasıl yazılır (Kaya Genç, çev.) İstanbul: Agora.

Eagleton, T. (2017). Bir şiir nasıl okunur? (Alphan Akgül, çev.). Zeliha Güneş ve Gökhan Tunç (Ed.). Yeni türk edebiyatına giriş 1. Eskişehir: Anadolu Üniversitesi.

Eco, U. (1997). Yorum ve aşırı yorum. (Kemal Atakay, çev.). İstanbul: Can.

Eliot, T. S. (1934). Selected essays. London: Faber and Faber.

Freud, S. (1999). Sanat ve edebiyat. (Emre Kapkın, Ayşe Tekşen Kapkın, çev.). İstanbul: Payel.

Halman, T. S. (2008). İki soyut şiirin düşündürdükleri. Edebiyat ve kültür yazıları içinde (ss. 195-204), Ankara: Hece.

Kahraman, H. B. (1995). Melih cevdet anday'ın denemelerinde nesnellik-öznellik ikilemi ve etkileşiminin temellendirilmesi aracı olarak dünya. Şükrü Erbaş (ed.), Melih cevdet anday günleri 20-21 mayıs 1995. Ankara: Edebiyatçılar Derneği.

Kahraman, H. B. (Mayıs/Haziran 1994). Melih cevdet anday şiirinde Descartes'çı düşünce sorunsalları açısından bir yaklaşım. Sombahar, 23, ss. 40-46.

Kalpaklı, M. (2010). Bir çağ günümüze: Necatigil ve divan şiiri. Asfalt ovalarda yürüyen abdal: Behçet Necatigil içinde (ss. 25-39). İstanbul: Türkiye İş Bankası.

Kaplan, M. (2005). Şiir tahlilleri 1. İstanbul: Dergâh.

Kaplan, M. (1995). Tevfik Fikret: Devir-şahsiyet-eser. İstanbul: Dergâh.

Koçak, O. (2012). Kopuk zincir: Modern şiir üzerine denemeler. İstanbul: Metis.

Köprülü, F. (1976). Türk edebiyatında ilk mutasavvıflar. Ankara: Diyanet İşleri Başkanlığg.

Köprülü, F. (2011). Halûk'un Defteri. İnci Enginün ve Zeynep Kerman (ed.), Yeni türk edebiyatı metinleri 4 içinde (ss. 391-409). İstanbul: Dergâh.

Lav, E. B. (2015). Hasta adam. O. Kahyaoğlu (der.), Modern türkçe şiir antolojisi 1 içinde (s. 185). İstanbul: Ayrıntı.

Leitch, W.B. The norton anthology of theory and criticism. New York, London: W.W. Norton.

Loy, M. (2015). The lost lunar baedeker: poems of Mina Loy. New York: Farrar, Straus and Giroux.

Mehmet Âkif. (1966). Safahat. İstanbul: İnkılap ve Aka. 
Moore, M. (Yaz/Güz 1961). Paris Review - The Art of Poetry No. 4 (theparisreview.org)

Nâzım Hikmet. (2010). Bütün şiirleri. İstanbul: YKY.

Necatigil, B. (2013). Bütün eserleri. İstanbul: YKY.

Necip Fazıl. (1997). Çile. İstanbul: Büyük Doğu.

Orhan Veli. (2013). Bütün şiirleri. İstanbul: YKY.

Özer, Nilay. (2017). “Ölümün değil, yaşamın kuramcısı”: Stevens şiirinden öğrenmemiz gereken. Erişim adresi: https://t24.com.tr/k24/yazi/wallace-stevens, 1373

Özdemir Asaf. (2011). Çiçek senfonisi. İstanbul: YKY.

Platon. (2011). Diyaloglar. (Teoman Aktürel, çev.). İstanbul: Remzi.

Pound, E. (1973). Selected prose 1909-1965. A New Directions Book.

Ramazani, J. vd. (2003). Modern poetry vol 1. New York ve Londra: W.W. Norton \& Company.

Schiralli, M. (1981). Education and the demands of literature texts: poetic meaning. McGill Journal of education XVI(1), 21-31.

Shakespeare, W. Nasıl hoşunuza giderse. (Özdemir Nutku, çev.) İstanbul: Türkiye İş Bankası.

Şentürk, A. A. (2006). Osmanlı şiiri antolojisi. İstanbul: YKY.

Şinasi. (1945). Müntahabat-ı eş'arım. İstanbul: Akba.

Tanpınar, A. H. (2013). On dokuzuncu asır Türk edebiyatı tarihi. İstanbul: Dergâh.

Tanpınar, A. H. (2011). Bütün şiirleri. İstanbul: Dergâh.

Temizyürek, M. (2021, 17 Ocak). Şair hikmet burcunda. Erişim adresi: https://t24.com.tr/k24/yazi/sairhikmet-burcunda, 3037

Urgan, M. (2008). Ingiliz edebiyatı tarihi. İstanbul: YKY.

Ülgener, S. F. (2006). Zihniyet, aydınlar ve izm 'ler. İstanbul: Derin.

Wimsatt, W. K. \& Beardsley M. C. (1954). The intentional fallacy. The verbal icon (ss. 3-18). The University Press of Kentucky.

Wordsworth, W. \& Coleridge, S. T. (2005). Lyrical Ballads. R. L. Brett ve A. R. Jones (ed.). Londra ve Newyork: Routledge.

Yahya Kemal. (1969). Kendi gök kubbemiz. İstanbul: Millî Eğitim.

Yavuz, H. (2005). Edebiyat ve sanat üzerine yazllar. İstanbul: YKY.

Yavuz, H. (2006). Büyü'sün yaz. İstanbul: YKY.

Yücel, C. (2009). Bir siyasinin şiirleri. İstanbul: Türkiye İş Bankası.

Yücel, T. (2004). Melih cevdet anday’ın şiirinde uzam ve zamanın izinde. K. Özkan ve A. Akgül (Ed.), Bütün yüzyılları yaşadım içinde (ss.127-140). İstanbul: Alkım. 